\title{
The anatomical traits of trunk wood and their relevance to oak (Quercus robur $\mathrm{L}$.) vitality
}

\author{
Mirela Tulik
}

Received: 26 September 2013/Revised: 3 March 2014/ Accepted: 7 March 2014/Published online: 26 March 2014

(C) The Author(s) 2014. This article is published with open access at Springerlink.com

\begin{abstract}
Oaks' decline in vitality is attributed to a complex process that involves interactions of several factors leading to increased trees' mortality. This study investigates the structure of trunk wood of oaks with reference to its physiological role in hydraulic conductivity. On the basis of the crown condition, the oaks were classified into three health groups: healthy trees, declining trees and dead trees. Anatomical traits of wood, such as annual ring width, vessel density, vessel diameter of earlywood and theoretical hydraulic conductivity, were measured and calculated. The narrowest annual rings formed by the cambium were observed in dead oaks. These trees were also characterized by the smallest diameter of earlywood vessels, not only in the period of occurrence of dieback symptoms, but also during their whole life. It is suggested that the formation of narrow annual rings and earlywood vessels of small diameter increases susceptibility of a tree to decay. A reduced vessel diameter implies changes in hydraulic conductivity of oak trunks and thus impairs the water transport, which affects the health of trees. The process of oak decline is considered to have characteristics of natural selection and leads to the elimination of the weakest trees.
\end{abstract}

Keywords Tree decline $\cdot$ Hydraulic conductivity - Oak trees . Wood annual increment . Vessel diameter

Communicated by M. Meincken.

M. Tulik $(\bowtie)$

Department of Forest Botany, Faculty of Forestry, Warsaw

University of Life Sciences (WULS), Nowoursynowska St. 159,

02-776 Warsaw, Poland

e-mail: mirela.tulik@wl.sggw.pl

\section{Introduction}

Trees, the long-lived and largest land plants, are organisms of highly specialized cell systems, whose structure and functions were, in the course of evolution, adapted to the environment they lived in. The current forms and shapes that trees assume are the result of the ability of their cells to respond to the interaction of intracellular and extracellular factors (Kozlowski et al. 1991; Dobbertin 2005). Since the 1970s of the nineteenth century, the process of decline of oaks has been progressing in Europe on a regular basis (Thomas and Boza 1984; Oleksyn and Przybył 1987; Thomas 2008). It does not apply to dying specimens of this species, but to a massive elimination of trees from the forest stand (Kaus et al. 1995). Among the European species of oak, Quercus robur is more susceptible to decay than Quercus petrea (Ufnalski 2006). This is probably due to its lower resistance to drought (Dickson and Tomlinson 1996), which could be related to changes in groundwater availability which have occurred in the recent decades. The oak dieback phenomenon is also observed in Canada and the United States with reference to Quercus agrifolia and Quercus kellogii (Oak et al. 1996; Rizzo et al. 2005). There are also reports of its presence in Asia (Mosca et al. 2007). While diagnosing the phenomenon of declining oaks, models were developed to describe it, like the model of the three-step dying process, where "predisposing", "contributing", and "inciting" factors, respectively, (Manion 1981) play an essential role. The predisposing factors include, among others, the phenotype and unfavourable habitat changes (Thomas and Hartmann 1996; Szewczyk et al. 2011). The second group can include frequent and longlasting droughts, irruptive decrease in groundwater level, strong frost and tree damages caused by insects from the group of primary pests as well as fungal diseases. The 
factors described as "inciting" include mainly secondary pests (e.g. insects from Argillus and Scolytus genera), as well as fungi causing root rot (e.g. Armillaria spp.) (Bugała 2006).

The phenomenon of oak vitality decline is likely caused by specific sequential stress factors, differing in duration and intensity, that interfere with physiological processes (e.g. photosynthetic $\mathrm{CO}_{2}$ uptake). This can cause severe structural anomalies which could lead to the elimination of this tree species (Wargo 1996; Thomas et al. 2002). On the other hand, oak species are known to show morphological and physiological adaptations that enable them to delay the impact of unfavourable factors (e.g. drought). The morphological adaptations are, among others, a deep-reaching root system or the ability of mature trees to shed twigs (cladoptosis) (Klugmann and Roloff 1999; Rust and Roloff 2004). The physiological mode that contributes to delaying drought mainly concerns transpiration (Maseda and Fernández 2006). This process is effectively controlled by regulation of the stomatal closure. Oak trees represent two opposite water use strategies, i.e. isohydric and anisohydric (Dickson and Tomlinson 1996). Q. robur demonstrates a more isohydric behaviour than Quercus rubra due to the fact that it is more sensitive to water stress (Thomsen et al. 2013). This isohydric response protects wood from cavitation through avoidance of severe low water potentials, but it can cause eventual carbon starvation as stomatal closure shuts down photosynthesis, while respiration costs continue to deplete carbon stores (McDowell et al. 2008).

Wood is a source of information about environmental events that took place during its formation (Sass and Eckstein 1995; Tulik 2001; Fonti et al. 2009; MartinBenito et al. 2013). The process of wood formation includes post-cambial cell growth, which determines the diameter of cells, deposition of the secondary cell wall and in case of vessels, tracheids and fibres-also lignification. It is ended by programmed cell death (Plomion et al. 2001). The successive phases of wood formation are not predetermined but are plastic end-products of interactions between genotype, hormones and the environment (Savidge 2000). The external factors are considered to affect the onset, the end and the rate of the phases of cambial cell derivatives' differentiation and thus determine the morphology of woody cells. Wodzicki (1971) grouped the environmental factors into (1) basic conditions for formation of wood, such as temperature, moisture, nutrients in the soil, gravity and photoperiod and (2) occasional factors such as wind, fire, frost, floods, defoliation, forest management and air pollution. Among these factors, the content of water in the soil is one of the most relevant factors affecting the cambium activity and the formation of new wood cells (Larson 1994). Abe and Nakai (1999) showed that cell diameter of the tracheids decreased during the early stage of water deficit, followed by a reduction in the number of cells produced. Eckstein et al. (1977) indicated also that size of water-conducting elements in broadleaved trees reflects the availability of water during their formation. Reduced size of conductive wood cells is known to be a result of the turgor pressure loss in expanding cambial cell derivatives in limited water growth conditions (Abe et al. 2003).

Oak wood is made up of vessels, tracheids, fibres and parenchyma cells. Earlywood vessels are mainly responsible for the transport of water in trees, which is assumed to take place in the outermost tree ring only (type of ringporous wood, Fonti et al. 2009). The transport efficiency depends on the size of vessels' lumen (Cochard and Tyree 1990, Sperry and Sullivan 1992) because according to the Hagen-Poiseuille formula, water conductivity is proportional to the fourth power of the tracheary element diameter (Tyree and Zimmermann 2002; McElrone et al. 2004).

The aim of this study was, therefore, a retrospective analysis of earlywood vessels' diameter liable for hydraulic conductivity. The working hypothesis of the study was that any reduction in vessel lumen influences oak tree $(Q$. robur L.) vitality because of water transport reduction.

\section{Materials and methods}

The study was conducted on oak (Q. robur L.) trees from two areas located in the central part of Poland, i.e. in the Chojnów Forest District (Masovian Voivodship) and Krotoszyn Forest District (Wielkopolskie Voivodship, Table 1), where the process of oak decline has been observed for several years (Siwecki and Ufnalski 1998). The forest within each study site was dominated by $Q$. robur. The material was collected from the area of Chojnów Forest District in September 2008 and from Krotoszyn Forest District in June 2009. Thirty trees (15 from each study site) at the age of 30-40 years and the comparable total height (representing the highest biosocial positions-class II according to the Kraft's classification) were selected for the study. Oaks growing in the Chojnów Forestry District area will be referred to in this study as oaks from Chojnów, while those growing in the Krotoszyn Forestry District-as oaks from Krotoszyn. The selection of the trees for the study within each site was made on the basis of the crown condition (i.e. the degree of its defoliation, the presence of dead branches) and classified as (i) healthy, (ii) declining and (iii) dead trees. Healthy oaks were defined as a reference. Defoliation of their crowns is estimated at around $20 \%$. Trees with crown defoliation of 70-90 \% were considered declining. Trees with no leaves and withered branches constituted the group of dead oaks. These oaks died in the year preceding the collection of the 
Table 1 Characteristics of study sites

\begin{tabular}{|c|c|c|c|c|c|c|c|}
\hline & Location $^{\mathrm{a}}$ & $\begin{array}{l}\text { Forest habitat } \\
\text { type }^{\mathrm{a}}\end{array}$ & $\begin{array}{l}\text { Species } \\
\text { composition }^{\mathrm{a}}\end{array}$ & Soil type $\mathrm{a}^{\mathrm{a}}$ & $\begin{array}{l}\text { Mean } \\
\text { annual } \\
\text { temperature } \\
\left({ }^{\circ} \mathrm{C}\right)^{\mathrm{b}}\end{array}$ & $\begin{array}{l}\text { Annual } \\
\text { precipitation } \\
\text { sum }(\mathrm{mm})^{\mathrm{b}}\end{array}$ & $\begin{array}{l}\text { Relative } \\
\text { humidity } \\
(\%)^{\mathrm{c}}\end{array}$ \\
\hline $\begin{array}{l}\text { Chojnów } \\
\text { Forest } \\
\text { District }\end{array}$ & $\begin{array}{l}52^{\circ} 01^{\prime} 13^{\prime \prime} \mathrm{N} \\
21^{\circ} 05^{\prime} 16^{\prime \prime} \mathrm{E}\end{array}$ & $\begin{array}{l}\text { Fresh mixed } \\
\text { broadleaved } \\
\text { forest }\end{array}$ & $\begin{array}{l}\text { Quercus, } \\
\text { Betula, } \\
\text { Carpinus }\end{array}$ & $\begin{array}{l}\text { Proper pseudogley soil, strongly fresh, } \\
\text { developed from stony loamy sand } \\
\text { shallow overlying on silty loam, flat } \\
\text { area without slopes }\end{array}$ & $\begin{array}{l}8.3 \\
(\mathrm{SD}=1)\end{array}$ & $\begin{array}{l}498.9 \\
(\mathrm{SD}=75)\end{array}$ & 79 \\
\hline $\begin{array}{l}\text { Krotoszyn } \\
\text { Forest } \\
\text { District }\end{array}$ & $\begin{array}{l}51^{\circ} 41^{\prime} 37^{\prime \prime} \mathrm{N}, \\
17^{\circ} 25^{\prime} 54^{\prime \prime} \mathrm{E}\end{array}$ & $\begin{array}{l}\text { Fresh } \\
\text { broadleaved } \\
\text { forest }\end{array}$ & $\begin{array}{l}\text { Quercus, } \\
\text { Larix, Pine }\end{array}$ & $\begin{array}{l}\text { Brownish rusty soil, developed from } \\
\text { sand on sandy loam underlying on } \\
\text { loamy sand, flat area without slopes }\end{array}$ & $\begin{array}{l}8.9 \\
(\mathrm{SD}=0.9)\end{array}$ & $\begin{array}{l}534.1 \\
(\mathrm{SD}=79)\end{array}$ & 77 \\
\hline
\end{tabular}

$S D$ standard deviation

${ }^{a}$ Forest Management Plan of Chojnów Forest District and Krotoszyn Forest District for 2008-2017

b Data from Climate Research Unit and Tyndall Centre for 1970-2002 (Mitchell and Jones 2005)

c Documentation of Forest Research Institute in Sękocin, Warsaw, Poland, data for 2008-2012

plant material. Each group was represented by five oaks. The bark of dead oaks form Chojnów was affected by Agrilus biguttatus. During sampling, Operophtera brumata, Erannis defoliaria, Tortix viridana and Euproctis chrysorrhoea were observed on the foliage of oaks from Krotoszyn.

The material for the study consisted of wood samples taken from the tree trunk at $1.3 \mathrm{~m}$ height from the ground. Wood blocks covering all of the annual growth rings were obtained from the collected discs, along the radial direction. The blocks were then boiled in a solution of water, alcohol and glycerol (1:1:1 in a volume ratio), which allowed softening and air release in the wood. The material prepared this way was cut on an HM 440E sliding microtome in order to obtain cross sections through the wood at a thickness of $30 \mu \mathrm{m}$. The sections were moved onto glass slides and sealed in glycerol. These were studied under an Olympus BX61 light microscope, equipped with a motorized table, colour DP70 digital camera and Cell P, a software for archiving photos and computer image analysis. On the basis of microscopic analysis and photographic documentation of the wood sections, the following parameters were measured:

1. The width of all annual rings (covering early and latewood zones cumulatively) deposited by the cambium of oaks growing at Chojnów and Krotoszyn. The width of a total of 1,020 annual wood rings was measured.

2. The density of vessels in all annual rings of oak wood from Chojnów and Krotoszyn. The results were calculated in $\mathrm{mm}^{2}$ of annual wood growth.

3. The diameters $(D)$ of at least 20 earlywood vessels in all annual wood rings of oaks from Chojnów and Krotoszyn (all in each annual ring in the field of vision at magnification of $40 \times$ ). In total, the diameter of at least 20,400 earlywood vessels was calculated. Data regarding the earlywood vessel diameter were used to calculate hydraulically weighted diameter $(D s)$ and potential hydraulic conductivity using the HagenPoiseuille formula.

Hydraulically weighted diameter was computed using an estimator defined by Sperry and Sullivan (1992):

$D s=\Sigma D^{5} / \Sigma D^{4}$

Data concerning the hydrostatic pressure gradient that pulls water from roots were not available at the time of tree sampling. Therefore, potential (theoretical) hydraulic conductivity ( $K \mathrm{p}$ ) was calculated according to the HagenPoiseuille formula (Sterck et al. 2008) as follows:

$K \mathrm{p}=\left(\pi \rho_{\mathrm{w}} / 128 \eta\right) \times \mathrm{VD} \times D_{\mathrm{s}}^{4}$

where $K \mathrm{p}$ is the potential specific stem conductivity (in $\mathrm{kg} \mathrm{m}^{-1} \mathrm{MPa}^{-1} \mathrm{~s}^{-1}$ ), $\eta$ is the viscosity coefficient of water at $20{ }^{\circ} \mathrm{C}\left(1.002 \times 10^{-3} \mathrm{~Pa} \mathrm{~s}\right.$ at $\left.20^{\circ} \mathrm{C}\right), \rho_{\mathrm{w}}$ is the density of water at $20{ }^{\circ} \mathrm{C}\left(998.2 \mathrm{~kg} \mathrm{~m}^{-3}\right.$ at $\left.20{ }^{\circ} \mathrm{C}\right), \mathrm{VD}$ is the vessel density and $D s$ is the hydraulically weighted diameter (in $\mathrm{m}$ ).

The determined wood parameters were averaged for five oaks from each health group and for 5-year periods to show general developmental tendencies more clearly. In total, the data covered the last 30 years of trees' growth, corresponding to the calendar years from 1978 to 2007 in case of oaks growing at Chojnów and from 1979 to 2008 for oaks from Krotoszyn. The samples are thus matched according to the year of ring formation but not necessarily of the tree age or the age at breast height.

To examine differences between oak groups in anatomical properties of wood and hydraulic conductivity, the datasets were first tested for normal distribution and the homogeneity of variance. Then, in order to compare the 
Fig. 1 Change in the width of wood increments in the stem of oak trees, representing different health conditions at the time of sampling. Wood increment width was calculated as the mean for five trees belonging to the group of healthy, declining and dead oaks from Chojnów (a) and Krotoszyn (b) and for 5 -year periods. Vertical bars denote SEs
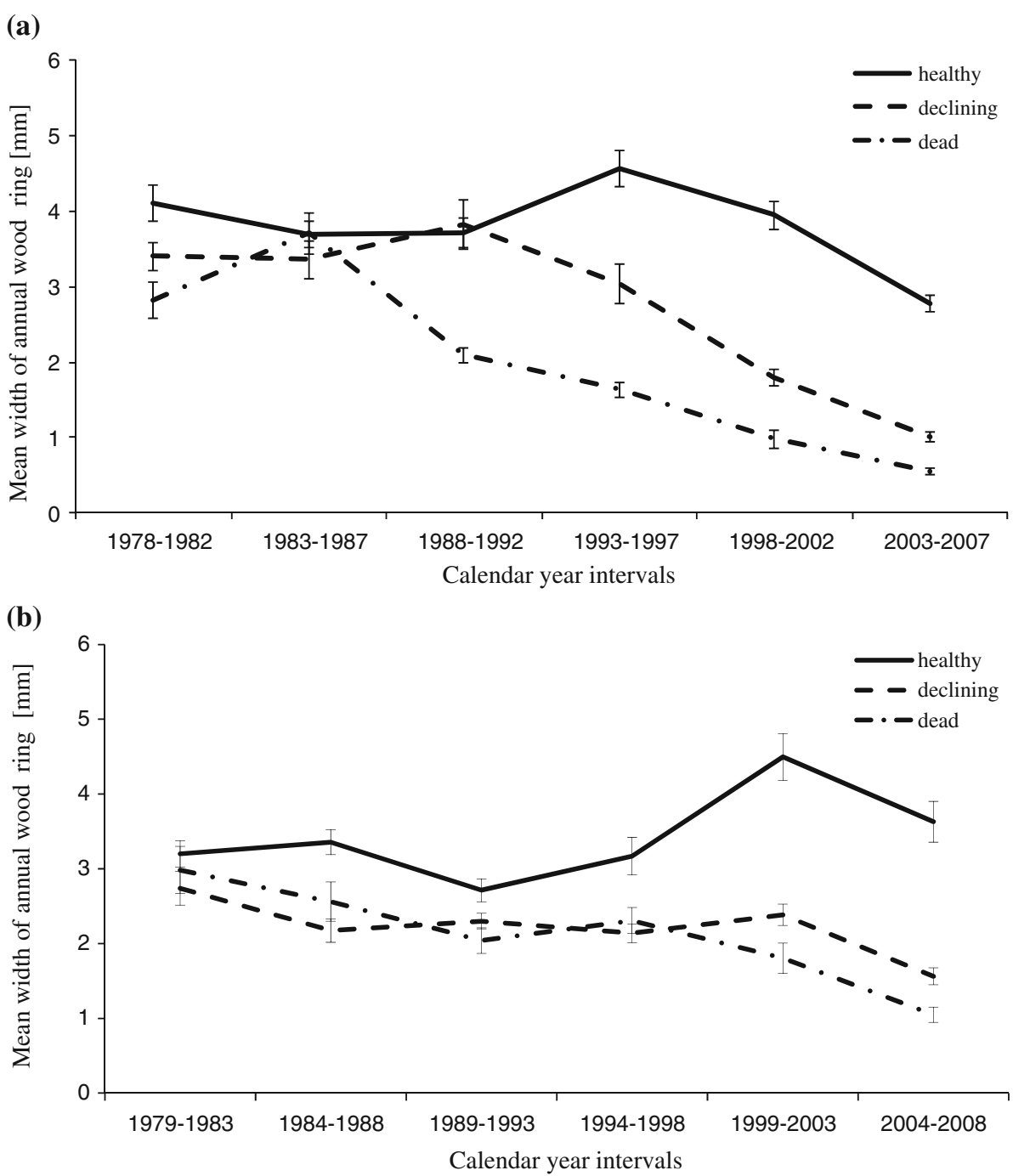

means, a Tukey's test was performed. Significance was determined at $p<0.05$. All statistical calculations were done with SAS software, version 9.0.

\section{Results}

Width of annual rings

In the first 5 years (1978-1982), the average width of annual ring in healthy oaks from Chojnów was $4.11 \mathrm{~mm}$ ( $\mathrm{SE}=0.23$ ), which was significantly higher than the one in dead oaks, i.e. $2.82 \mathrm{~mm}$ ( $\mathrm{SE}=0.23$, Fig. 1a). The ring width in trees of different groups did not vary between the groups of healthy and declining oaks during the next 5-year span (1983-1987) and in the following period (1988-1992). In the next 5-year periods, there were significant differences in the width of annual increments between the groups of oaks. The widest annual rings were formed in healthy oaks during 1993-1997, in declining oaks during 1988-1992, and in dead oaks during 1983-1987. The narrowest annual increments for all oaks appeared in the last 5-year period; their width reached $2.77 \mathrm{~mm} \quad(\mathrm{SE}=0.11)$ for healthy oaks, $1.01 \mathrm{~mm}$ $(\mathrm{SE}=0.06)$ for declining oaks and $0.55 \mathrm{~mm}(\mathrm{SE}=0.04)$ for dead oaks. Similar variations in the average width of annual rings appeared in the oaks from Krotoszyn (Fig. 1b). However, unlike the oaks from Chojnów, in the first 5-year period (1979-1983), the average width of the annual ring of healthy oaks reached $3.20 \mathrm{~mm}(\mathrm{SE}=0.18)$. This value was not significantly greater than one for declining oaks, i.e. $2.74 \mathrm{~mm}(\mathrm{SE}=0.23)$, or for dead trees, i.e. $2.98 \mathrm{~mm}(\mathrm{SE}=0.32)$. During the second 5-year span, and later on, significantly wider annual rings were formed by the cambium of healthy oaks, compared to dead oaks. In the last phase (2004-2008), the width of the annual ring of dead oak wood reached its lowest, i.e. $1.05 \mathrm{~mm}$ $(\mathrm{SE}=0.1)$. The ring was more than 3 times narrower than 


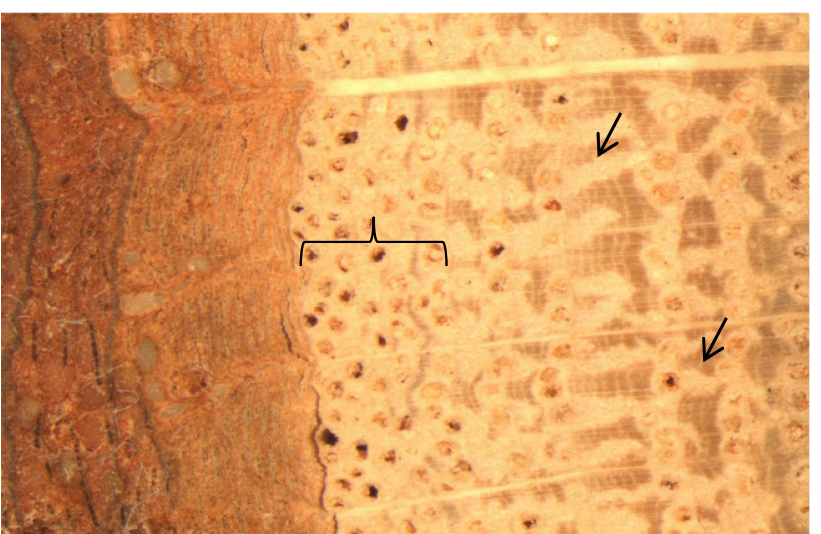

Fig. 2 Cross section through wood of dead oaks from Chojnów observed under an Olympus SZX9 stereomicroscope system equipped with an Olympus ColorView IIIu camera and getIT software at $\times 63$. Close to the bark, a sequence of a few annual rings comprising very narrow increments is marked by brackets. The abatement of latewood zone is intrinsic to the annual ring width decrease, while the earlywood zone is almost unchanged. The radial arrangement of latewood vessels within wider annual increments is showed with arrows

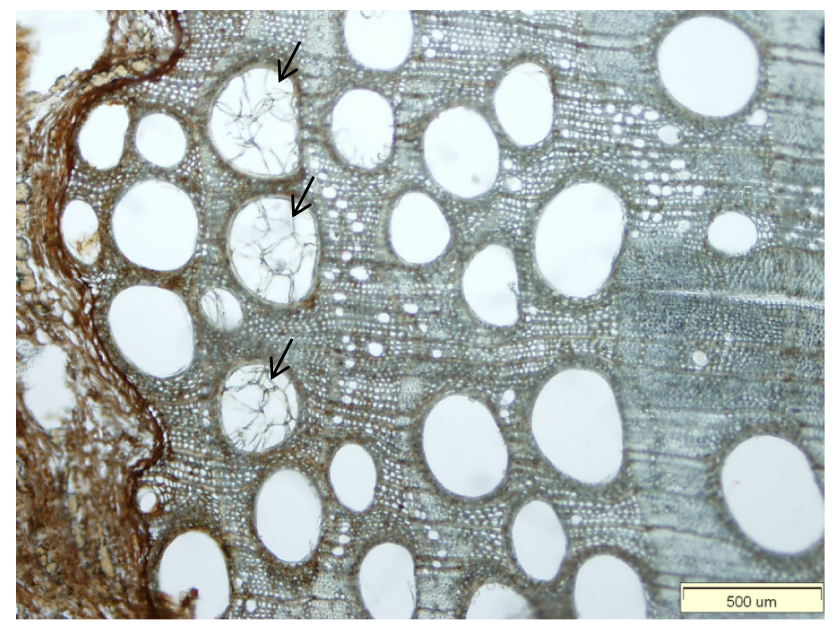

Fig. 3 Transverse section through wood of declining oaks from Krotoszyn. Within the youngest and incessantly forming annual increment, the lumen of vessels filled with tyloses is indicated by arrows. Observation was performed under a light microscope Olympus BX61 equipped with an Olympus DP70 camera and Cell $P$ software

in healthy oaks. The differences in the width of annual wood increments between the groups of healthy and declining oaks occurred in years: 1984-1988, 1994-1998 and during the next two 5-year spans. The width of the annual ring for healthy oaks attained its highest value in the years 1999-2003; this was significantly higher than in the other two groups of oaks. Starting from 2004, the average width of annual increments was reduced for both healthy and declining oaks, but in the case of healthy oaks, they were significantly wider, i.e. more than 2 times, in comparison with declining oaks.

The share of earlywood and latewood within the annual wood increment was not measured during this study. However, the relation between the width of annual increment and the share of earlywood and latewood could be seen clearly on microscopic pictures. Regardless of the health condition of trees, a simple relation appeared in respect to the last five rings: the narrower the increment, the lower the share of latewood (Fig. 2). It was also observed that in last incessantly forming ring in declining oaks from Krotoszyn, the lumen of earlywood vessels was filled with tyloses (Fig. 3).

\section{Density of earlywood vessels}

In the first two 5-year periods, there were no significant differences in the density of earlywood vessels, i.e. in their number per $1 \mathrm{~mm}^{2}$ of annual wood increment, among the analysed groups of oak from Chojnów (Fig. 4a). The intergroup differences emerged during the years 1988-1992 and in the subsequent time phases analysed. Since 1993, the healthy oak wood has been always characterized by the highest density of earlywood vessels and the dead oaks by the lowest one. The number of earlywood vessels per $1 \mathrm{~mm}^{2}$ of wood in dead oaks was more than 7 times lower than in healthy oaks in the last 5 -year period. It was observed that in all the analysed groups of oak trees, the first annual rings of wood were characterized by the highest density of earlywood vessels. However, in 1988-1992, when the density of earlywood vessels per $1 \mathrm{~mm}^{2}$ of wood of declining and dead oaks was diminishing, an upward trend appeared in the wood of healthy oak trees. Only starting from the next 5-year interval, a reduction in the value of this parameter occurred, which continued until the last time interval.

Similarly to the oaks from Chojnów, there were no significant differences in the distribution of earlywood vessels per $1 \mathrm{~mm}^{2}$ of wood in the three groups of oak from Krotoszyn, during 1979-1983 (Fig. 4b). Differences with $p<0.05$ appeared between the groups of healthy and dead oak trees and the healthy and declining ones in all the subsequent 5 -year periods analysed. The density of earlywood vessels in healthy oak wood has been always significantly higher, with its maximum occurring during 1999-2003. In 2004-2008, the vessel density in the annual growth of healthy oak wood was significantly higher, compared with the declining and dead oaks. In the last 5 -year period, the wood of healthy oaks contained about 16 earlywood vessels per $\mathrm{mm}^{2}(\mathrm{SE}=1.66)$, with $5 / \mathrm{mm}^{2}$ $(\mathrm{SE}=0.4)$ for declining oak trees and $3 / \mathrm{mm}^{2}(\mathrm{SE}=0.48)$ for dead oak trees. The highest density of earlywood 
Fig. 4 Variation in mean density of earlywood vessels' distribution in the trunk of oak trees, representing different health conditions at the time of sampling. Density of vessels was defined as the number of earlywood vessels per $\mathrm{mm}^{2}$ of annual increments and calculated as a mean for five trees representing the group of healthy, declining and dead oaks from Chojnów (a) and Krotoszyn (b), respectively, and for 5-year periods. Vertical bars denote SEs

\section{(a)}

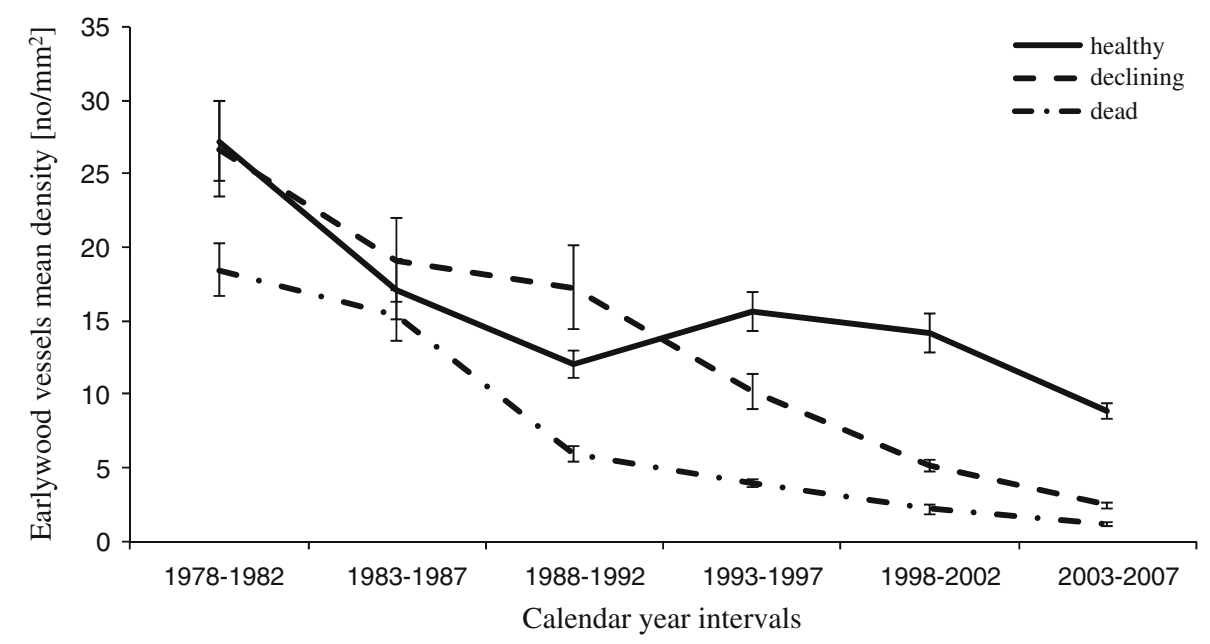

(b)

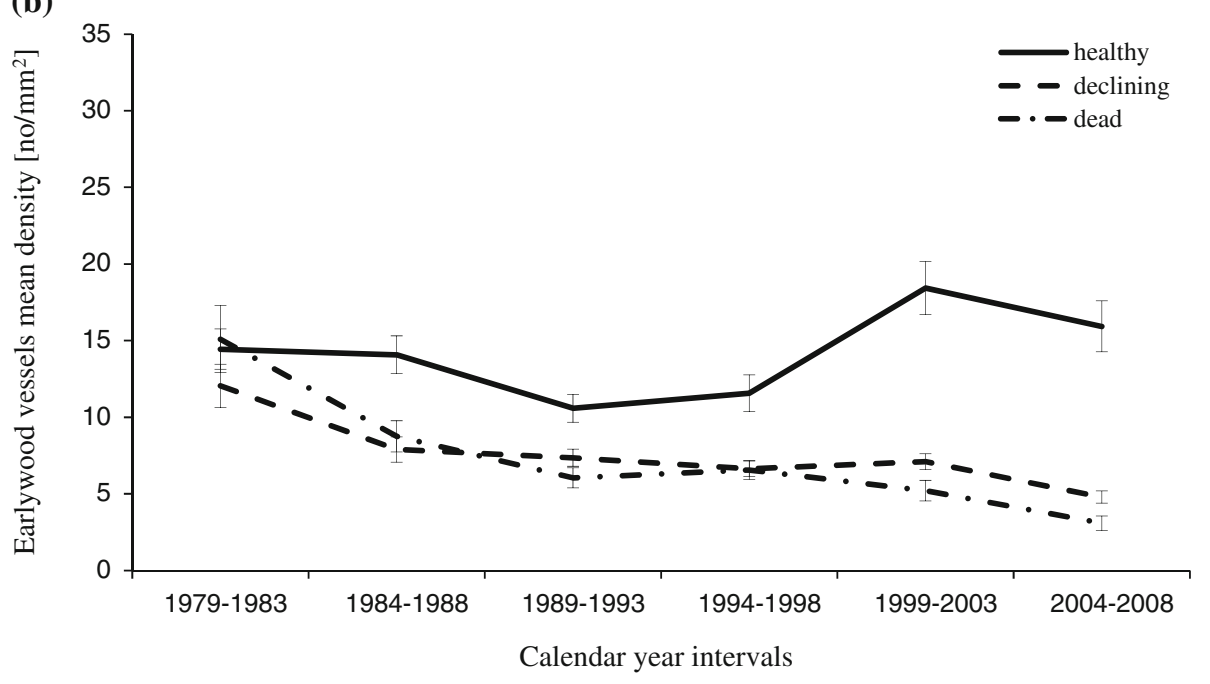

vessels in dead and declining oak trees was observed in annual increments in the first 5 years. In the subsequent years, it decreased. In the wood of declining oak trees, the number of earlywood vessels per $1 \mathrm{~mm}^{2}$ of the annual growth decreased by more than 2.5 times, when comparing the period of 1979-1983 with that of 2004-2008, and it was 4.9 times lower than in the corresponding period for dead oaks.

\section{Diameter of earlywood vessels}

In all analysed groups of oaks from Chojnów, the earlywood vessel diameter increased together with the age of the tree during the first 20 years, and the later changes were only a minor fluctuation (Fig. 5a). In the first 5-year period (1978-1982), there occurred differences in the earlywood vessel diameter between the healthy and dead oak trees. The healthy oak wood was characterized by significantly larger diameter of earlywood vessels, that is $0.23 \mathrm{~mm}$
$(\mathrm{SE}=0.011)$, while for the dead oaks, it reached the value of $0.19 \mathrm{~mm}$ (SE $=0.013)$. In the years 1988-1987, there occurred differences in the earlywood vessel diameter among the three groups of trees. Significantly, the greatest diameter of the earlywood vessels was found in the healthy oak wood and the smallest (by $70 \mu \mathrm{m}$ smaller compared to the healthy oak wood) in the dead oak wood. From the year 1993 onwards, the diameter began to decrease in the declining and dead oaks, while the upward trend still continued in healthy oaks. However, in the years 1993-1997, the vessel diameter in healthy oak wood did not differ $(p<0.05)$ in comparison with declining oaks. In the last phase (2003-2007), the vessel diameter was the largest, i.e. $0.39 \mathrm{~mm}(\mathrm{SE}=0.07)$ in the healthy oak wood, whereas in declining oaks, it was $0.34 \mu \mathrm{m}(\mathrm{SE}=0.005)$ and in dead oaks $-0.27 \mathrm{~mm}(\mathrm{SE}=0.004)$, i.e. nearly 1.5 times smaller than in healthy oaks. An increase in the diameter of earlywood vessels corresponding to the age of the tree was also observed in all groups of oak trees from Krotoszyn, being 
Fig. 5 Change in the average earlywood vessels' diameters of the trunk oak trees, representing different health conditions at the time of sampling. The mean diameter was calculated for five trees representing the group of healthy, declining and dead oaks from Chojnów (a) and Krotoszyn (b), respectively, and for 5-year periods. Vertical bars denote SEs
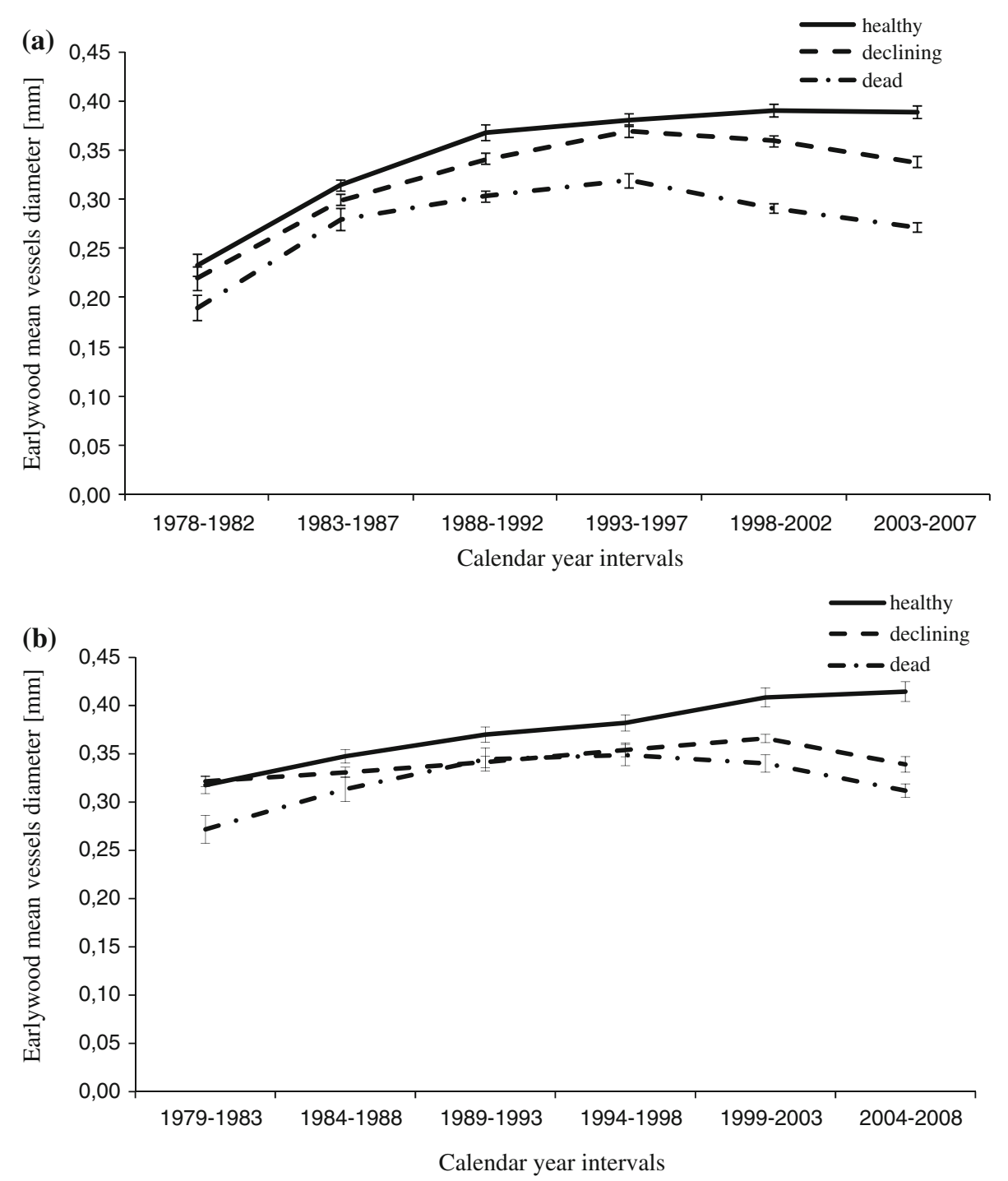

most prominent in the wood of healthy oak trees (Fig. 5b). In the first 5-year period (1979-1983), the wood of healthy and declining oaks was characterized by a significantly larger diameter of the earlywood vessels, i.e. $0.32 \mathrm{~mm}$, while it attained the value of $0.27 \mathrm{~mm}$ in dead oak trees. In the penultimate period of 5 years (1999-2003), there was a reduction in earlywood vessel diameter in the declining and dead oak trees, but it increased in the wood of healthy oak trees. In the years 2004-2008, that is the last 5-year period, the diameter of earlywood vessels was significantly higher in healthy oak trees than in other two, reaching $0.41 \mathrm{~mm}(\mathrm{SE}=0.01)$ for healthy, $0.34 \mathrm{~mm}$ $(\mathrm{SE}=0.008)$ for declining and $0.31 \mathrm{~mm}(\mathrm{SE}=0.007)$ for dead oaks.

Potential hydraulic conductivity

The curves drawn to illustrate changes in the values of the theoretical hydraulic conductivity of the oak trunk wood from Chojnów and Krotoszyn were similar in shape, especially for healthy oaks, and showed a clear upward trend during 25-year time span (Fig. 6a, b). The maximum value of this variable for the healthy oaks from Chojnów and Krotoszyn was recorded in the penultimate phase. On both sites, the hydraulic conductivity remained the minimum for dead oaks. During the whole period of study, the group of healthy oaks from Chojnów was significantly (with $p<0.05$ ) different from the group of dead trees in terms of potential water conductivity volume. In the first 5 -year period, the wood of healthy oak trunks was almost 6 times more effective in water conduction, but in the last phase, it was 30 times more effective. In the last three 5 -year intervals, there were differences among the three groups of oaks. The hydraulic conductivity of healthy oaks was significantly higher (1.6 times) in 1993-1997, almost 5.8 times higher during 1998-2002 and 6.8 times in the last 5 -year period in comparison with the group of declining oaks. However, in recent years, the water transport 
Fig. 6 The potential hydraulic conductivity of earlywood vessels in the trunk of oak trees, representing different health conditions at the time of sampling. It was calculated for five trees representing the group of healthy, weakened and dead oaks from Chojnów (a) and Krotoszyn (b), respectively, and for 5-year periods. Vertical bars denote SEs
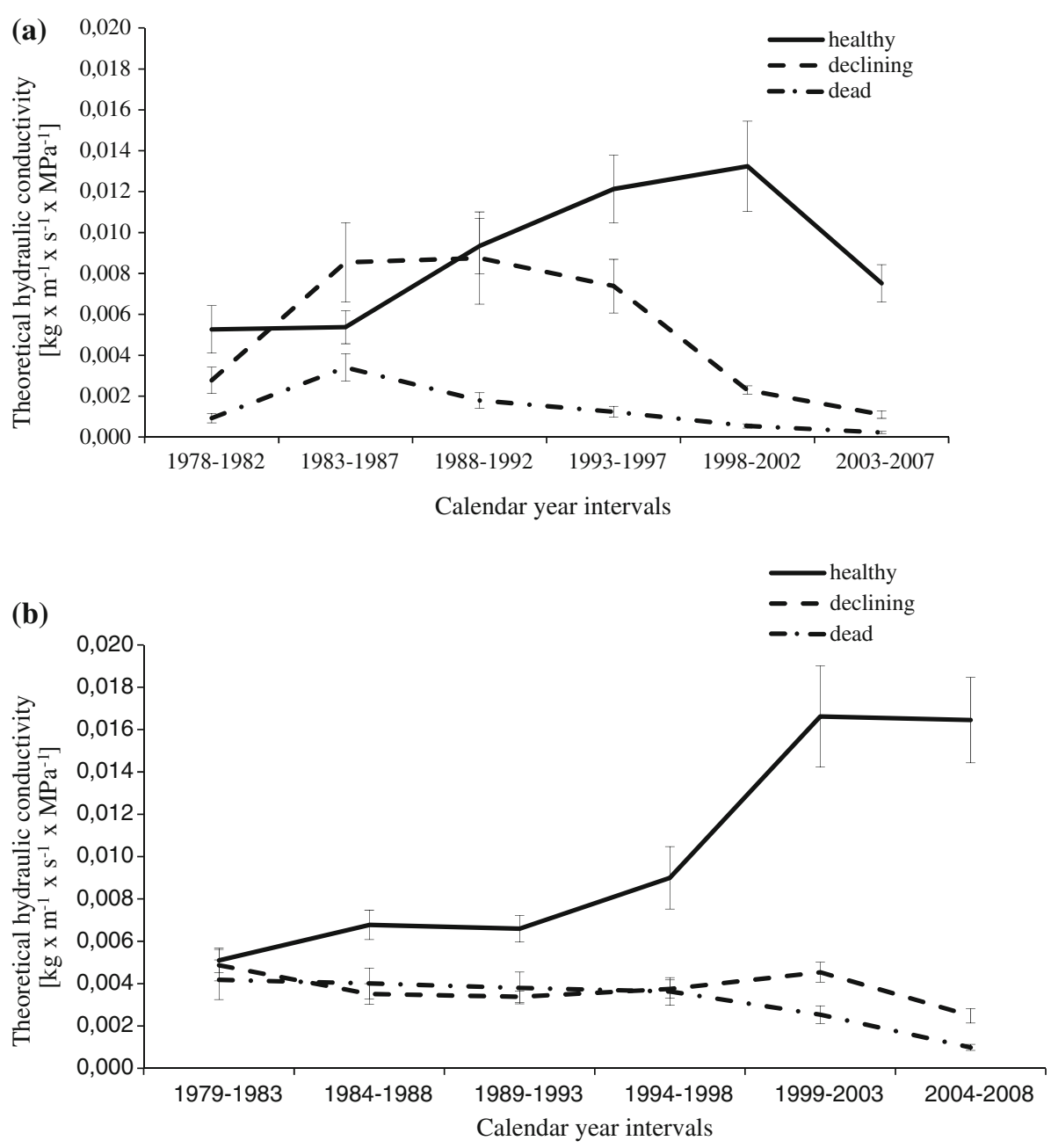

efficiency of oak tree trunks in all groups of trees showed a downward trend.

In the first 5-year period, no significant differences in the hydraulic conductivity of wood trunks were found among the three groups of oak trees from Krotoszyn. The efficiency of water conduction in healthy oak trees started increasing from the second 5-year period as compared with the groups of declining and dead oaks, for which the hydraulic conductivity in the last 5-year period was significantly (more than 16 times) smaller in comparison with the healthy oak group. Also for the declining oak trees, there was no clear upward trend for the hydraulic conductivity efficiency of the trunk wood during the period analysed, just like in the case of the healthy oaks. Even in the period of 1983-1993, it did not differ significantly from the dead oak group. The largest value of the theoretical hydraulic conductivity for the declining oak trees was obtained in the penultimate period of 5 years, and this was 1.8 times higher than for the dead oak group and 3.7 times lower than for the healthy oaks. After this period, the value of the hydraulic conductivity for healthy oaks remained constant, while a clear reduction in the value of this parameter was observed for the declining and dead oaks.

\section{Discussion}

The observed changes in the structure of wood in oak trees with different health status in the year of the study are a function of the tree age and environmental factors. The width of annual rings measured at the breast height shows an overall downward trend corresponding to the increasing tree age, except for the juvenile growth phase and juvenile wood (Zobel and Sprague 1998). A similar downward trend was observed for oak trees, whereas the average width of the ring was always the highest for oaks classified as healthy and the lowest for those classified as dead. It seems that the persistence of difference in the width of the ring for trees of similar age and growing in similar environmental conditions (in reference to oak from Chojnów and Krotoszyn, respectively) may indicate the growth 
potential and the consequent longevity of particular trees, which in turn may determine their susceptibility to decay. Survival of a tree is dependent, however, on its efficiency of water conduction rather than on the width of growth increments, especially in ring-porous species (Carlquist 1975; Zimmermann 1983). The elements conducting water most efficiently are the earlywood vessels (Tyree and Ewers 1991), and their development is controlled by genetic factors (Zobel and van Buijtenene 1989) and also by environmental ones, like the availability of water (Hsiao 1973; Fritts 2001). The enlargement of cambial cell derivatives that undergo differentiation towards vessel elements is a turgor-driven process which depends strictly on solute accumulation and cellular water uptake (Langer et al. 2002).

As in other species with ring-porous wood, the variation in the diameter of the earlywood vessels in three health groups of oak took the shape of a sigmoid curve (HelińskaRaczkowska 1994; Helińska-Raczkowska and Fabisiak 1999), which means that the diameter increased along the radius, i.e. with the distance from the pith or the age of the cambium until reaching a value around which it fluctuated. It should be emphasized that the widest vessels were always in the wood of trees representing the group of healthy oaks, whereas the wood of dead oak trees was characterized by the smallest diameter of vessels. A concomitant decrease in earlywood vessels' density per unit of the annual ring surface was noted: the lowest for the trees from the group of dead oaks and the highest for the healthy ones, contributing to the reduction in the potential hydraulic conductivity of oak trees represented particularly in the groups of declining and dead trees. The increase in the vessel diameter and the consequent improved water conductivity possibly constitute a mechanism of adaptation to changing environmental conditions and a response to stress factors affecting the growth potential and reproduction capacity of the tree (Drew et al. 2009). This is in line with the Tyree's hypothesis (2003), which assumes that the growth rates are hydraulically mediated. Thus, the adverse changes in structural wood parameters important for hydraulic conductivity, such as the diameter of tracheary elements, may indicate a lack of adaptability to changing environmental conditions and may result in intensification of the decline symptoms.

A similar response concerning the increase in the vessels' lumen under stress factors causes water-limited growth conditions. Corcuera et al. (2004a) observed that the size of earlywood vessels in ring-porous oaks increased together with increasing water deficit. However, conflicting results were also showed by Corcuera et al. (2004b) or Eilmann et al. (2006). Lovisolo and Schubert (1998) suggested two possible mechanisms concerning the influence of water stress on hydraulic conductance of shoots. The first mechanism is channelled by plants during moderate water stress when the reduction in vessel size may have an adaptive character. The second one is induced by a short and more severe water stress, which leads to vessels' embolism. Reduced lumen of vessels in wood of oaks from the declining group, subjected to different types of unfavourable factors, may contribute to control of water transport and to reduction in vulnerability to cavitation and embolism. It is known that the large earlywood vessels contribute to the greater part of water flow throughout the shoot/trunk, but due to their large lumen diameter, these vessels are vulnerable to embolization (Cochard et al. 1997). Due to the fact that the plants function at constant risk with regard to hydraulic conductance (Carlquist 1988; Hacke et al. 2006), the transport of water is a matter of compromises between safety and efficiency. The method of the safe transport in oaks from declining group is considered to have not been sufficient under the impact of factors of both biotic and abiotic nature.

Levanič et al. (2011), on the other hand, by analysing the influence of drought on xylem hydraulic parameters and mortality of $Q$. robur, proposed that "the ability for hydraulic wood rebuild" can determine the successful survival of trees. It appears that the ability for "hydraulic reconstruction" is essential for the survival of an individual under the conditions of water stress. It should be noted, however, that Levanič et al. (2011) analysed the effect of only one factor, namely water stress. Dieback of oak trees, observed in the forest districts, is probably an outcome of the interaction of abiotic factors, including water availability, with defoliating insects, borer attack and pathogenic fungi (according to information from the staff from Chojnów Forest District and Krotoszyn Forest District). The presence of the tyloses in the earlywood vessels of the incessantly emerging annual wood increment is considered to have had impact on the reduction of the hydraulic conductance in declining oaks from Krotoszyn. The tyloses and gel substances were observed in the wood of weakened oaks by Woźny and Siwecki (1991). The authors postulated that modifications in the structure of conductive elements were caused by fungi belonging to Ceratocystis genus, which resulted in wood dysfunction. In the case of oaks from Krotoszyn, it could be also defoliation, which is known as a factor altering the water transport due to the fact that the lumen of its vessels was filled with tyloses (Fajvan et al. 2008).

On the other hand, it is known that the cambial activity and wood formation are processes dependent on the accessibility of photoassimilates (Eilmann et al. 2009). The crown of a declining oak tree was defoliated by approximately $80 \%$. It can therefore be assumed that the photosynthetic efficiency of declining oaks was lower, compared with the group of healthy trees, which could 
affect the meristematic activity of the cambium and consequently the wood formation process during growth seasons. Thus, the results of this study may have confirmed that the individuals best adapted to the changes of the external environment survive in the "struggle for existence", in accordance with the Darwin's law of natural selection.

\section{Conclusions}

1. Formation of narrow growth rings and vessels of small diameter over the course of a tree's life is relevant to decline in tree vitality.

2. Hydraulic conductivity decreases in response to reduction in the vessel diameter as well as vessels' density, which during the complex process of oak decline contributes to the diminishing of the vigour of trees and to their death.

3. The hydraulic reconstruction under stress condition seems to be a key for survival.

Acknowledgments The author would like to thank Jacek Adamczyk from Warsaw University of Life Sciences and Jerzy Karczewski from Silesian University for their assistance with data analysis. The English grammar has been revised by native speaker of the Translation Office Lingua Nova Sp. z o.o. Author is grateful to Professor M. Iqbal from the Department of Plant Production Khartoum, Sudan for helpful comments on the manuscript.

Open Access This article is distributed under the terms of the Creative Commons Attribution License which permits any use, distribution, and reproduction in any medium, provided the original author(s) and the source are credited.

\section{References}

Abe H, Nakai T (1999) Effect of the water status within a tree on tracheids morphogenesis in Cryptomeria japonica D. Don. Trees 14:124-129

Abe H, Nakai T, Utsumi Y, Kagawa A (2003) Temporal water deficit and wood formation in Cryptomeria japonica. Tree Physiol 23:859-863

Bugała W (2006) Dęby. Quercus robur L. Quercus petraea (Matt.) Liebl. Instytut Dendrologii PAN, Poznań

Carlquist S (1975) Ecological strategies of xylem evolution. University of California Press, Berkeley

Carlquist S (1988) Comparative wood anatomy. Springer, New York

Cochard H, Tyree MT (1990) Xylem dysfunction in Quercus: vessel size, tyloses, cavitation, and seasonal changes in embolism. Tree Physiol 6:393-407

Cochard H, Peiffer M, Le Gall K, Granier A (1997) Developmental control of xylem hydraulic resistances and vulnerability to embolism in Fraxinus excelsior L.: impacts of water relations. J Exp Bot 48:655-663

Corcuera L, Camarero JJ, Gil-Pelegrín E (2004a) Effects of a severe drought on growth and wood anatomical properties of Quercus faginea. IAWA J 25(2):185-204
Corcuera L, Camarero JJ, Gil-Pelegrin E (2004b) Effects of a severe drought on Quercus ilex growth and xylem anatomy. Trees 18:83-92

Dickson RE, Tomlinson PT (1996) Oak growth, development and carbon metabolism in response in water stress. Ann Sci For 53:181-196

Dobbertin M (2005) Tree growth as indicator of tree vitality and of tree reaction to environmental stress: a review. Eur J Forest Res 124:319-333

Drew D, Downem G, O'Grady A, Read J, Worledge D (2009) High resolution temporal variation in wood properties in irrigated and non-irrigated Eucalyptus globulus. Ann For Sci 66:406-415

Eckstein D, Frisse E, Quiehl F (1977) Wood anatomical studies of a beech tree to demonstrate anthropogenic influences on its environment. Angew Bot 51:47-56

Eilmann B, Weber P, Rigling A, Eckstein D (2006) Growth reactions of Pinus sylvestris L. and Quercus pubescens Willd. to drought years at a xeric site in Valais, Switzerland. Dendrochronologia 23:121-132

Eilmann B, Zweifel R, Buchmann N, Fonti P, Rigling A (2009) Drought-induced adaptation of the xylem in Scots pine and pubescent oak. Tree Physiol 29:1011-1020

Fajvan MA, Rentch J, Gottschalk K (2008) The effects of thinning and gypsy moth defoliation on wood volume growth in oaks. Trees 22:257-268

Fonti P, von Arx G, Garcia-Gonzales I, Eilmann B, Sass-Klassen U, Gärtner H, Eckstein D (2009) Studying global change through investigation of the plastic response of xylem anatomy in tree rings. New Phytol 185:42-53

Fritts HC (2001) Tree rings and climate. Academic Press, London

Hacke UG, Sperry JS, Wheeler JK, Castro L (2006) Scaling of angiosperm xylem structure with safety and efficiency. Tree Physiol 26:689-701

Helińska-Raczkowska L (1994) Variation of vessel lumen diameter in radial direction as an indication of the juvenile wood growth in oak (Quercus petraea Liebl.). Ann Sci For 51:283-290

Helińska-Raczkowska L, Fabisiak E (1999) Radial variation of vessel lumen diameter as an indicator of the juvenile growth period in ash (Fraxinus excelsior L.). Holz als roh-u. Werkstoff 57: 283-286

Hsiao TC (1973) Plant response to water stress. Ann Rev Plant Physiol 24:519-570

Kaus A, Schmitt V, Simon A, Wild A (1995) Microscopical and mycological investigations on wood of pedunculate oak (Quercus robur $\mathrm{L}$.) relative to the occurrence of oak decline. J Plant Physiol 148:302-308

Klugmann K, Roloff A (1999) Ökophysiologische Bedeutung von Zweigabsprüngen (Kladoptosis) unter besonderer Berücksichtigung der Symptomatologie von Quercus robur L. Forstw Cbl 118:271-286

Kozlowski TT, Kramer PJ, Pallardy SG (1991) The physiological ecology of woody plants. Academic Press, San Diego

Langer K, Ache P, Geiger D, Stinzing A et al (2002) Poplar potassium transporters capable of controlling $\mathrm{K}^{+}$homeostasis and $\mathrm{K}^{+}$dependent xylogenesis. Plant J 32:997-1009

Larson PR (1994) The vascular cambium, Structure and development. Springer, New York

Levanič T, Čater M, McDowell NG (2011) Associations between growth, wood anatomy, carbon isotope discrimination and mortality in a Quercus robur forest. Tree Physiol 31:298-308

Lovisolo C, Schubert C (1998) Effects of water stress on vessel size and xylem hydraulic conductivity in Vitis vinifera L. J Exp Bot 49:693-700

Manion PD (1981) Tree disease concepts. Prentice Hall, New Jersey

Martin-Benito D, Beeckman H, Caňellas I (2013) Influence of drought on tree rings and tracheid features of Pinus nigra and 
Pinus sylvestris in a mesic Mediterranean forest. Eur J For Res 132:33-45

Maseda PH, Fernández RJ (2006) Stay wet or else: three ways in which plants can adjust hydraulically to their environment. J Exp Bot 57:3963-3977

McDowell N, Pockman WT, Allen CD et al (2008) Mechanisms of plant survival and mortality during drought: why do some plants survive while others succumb to drought? New Phytol 178: 719-739

McElrone AJ, Pockman WT, Martinez-Vilalta J, Jackson RB (2004) Variation in xylem structure and function in stems and roots of trees to $20 \mathrm{~m}$ depth. New Phytol 163:507-517

Mitchell TD, Jones P (2005) An improved method of constructing a database of monthly climate observations and associated highresolution grids. Int J Climatol 25:693-712

Mosca E, Montecchio L, Stella L, Garbaye J (2007) Short-term effect of removing tree competition on the ectomycorrhizal status of a declining pedunculate oak forest (Quercus robur L.). For Ecol Manag 244:129-140

Oak S, Tainter F, Williams J, Starkey D (1996) Oak decline risk rating for the southeastern United States. Ann Sci For 53:721-730

Oleksyn J, Przybył K (1987) Oak decline in the Soviet Union. Scale and hypotheses. Eur J For Path 17:321-336

Plomion Ch, Leprovost G, Stokes A (2001) Wood formation in trees. Plant Physiol 127:1513-1523

Rizzo DM, Garbelotto M, Hansen E (2005) Phytophthora ramorum: integrative research and management of an emerging pathogen in California and Oregon forest. Annu Rev Phytopathol 43:309-335

Rust S, Roloff A (2004) Acclimation of crown structure to rough in Quercus robur L.: intra and inter-annual variation of abscission and traits of shed twigs. Basic Appl Ecol 5:283-291

Sass U, Eckstein D (1995) The variability of vessel size in beech (Fagus sylvatica L.) and its ecophysiological interpretation. Trees 9:247-252

Savidge RA (2000) Intrinsic regulation of cambial growth. J Plant Growth Regul 20:52-77

Siwecki R, Ufnalski K (1998) Review of oak stand decline with special reference to the role of drought in Poland. Eur J For Path 28:99-112

Sperry JS, Sullivan JEM (1992) Xylem embolism in response to freeze-thaw cycles and water stress in ring porous, diffuse porous and conifer species. Plant Physiol 100:605-613

Sterck FJ, Zweifel R, Sass-Klaassen U, Qumruzzaman C (2008) Persisting soil drought reduces leaf specific conductivity in Scots pine (Pinus sylvestris) and pubescent oak (Quercus pubescens). Tree Physiol 28:529-536

Szewczyk W, Dudek M, Baranowska M (2011) Evaluation of oak tree conditions on the basis of losses in the assimilation apparatus of selected oak stands in Sulęcin forest district. Acta Sci Pol Silv Colendar Rat Ind Lignar 10:37-47

Thomas FM (2008) Recent advances in cause-effect research on oak decline in Europe. CAB Rev Perspect Agric Vet Sci Nutr Nat Resour 3(037):1-12

Thomas WD Jr, Boza CA (1984) The oak decline complex. J Arboric 10(6): 170-177

Thomas FM, Hartmann G (1996) Soil and tree water relations in mature oak stands of Northern Germany differing in the degree of decline. Ann Sci For 53:697-720

Thomas FM, Blank R, Hartmann G (2002) Abiotic and biotic factors and their interactions as causes of oak decline in Central Europe. For Path 32:277-307

Thomsen JE, Bohrer G, Matheny AM et al (2013) Contrasting hydraulic strategies during dry soil conditions in Quercus rubra and Acer rubrum in a sandy site in Michigan. Forests 4:1106-1120

Tulik M (2001) Cambial history of Scots pine trees (Pinus sylvestris) prior and after the Chernobyl accident as encoded in the xylem. Environ Exper Bot 46(1):1-10

Tyree MT (2003) Hydraulic limits on tree performance: transpiration, carbon gain and growth of trees. Trees 17:95-100

Tyree MT, Ewers FW (1991) The hydraulic architecture of trees and other woody plants. New Phytol 119:345-360

Tyree MT, Zimmermann MH (2002) Xylem structure and the ascent of sap, 2nd edn. Springer, New York

Ufnalski K (2006) Teleconnection of 23 modern chronologies of Quercus robur and $Q$. petraea from Poland. Dendrobiology 55:51-56

Wargo PM (1996) Consequences of environmental stress on oak: predisposition to pathogens. Ann Sci For 53:359-368

Wodzicki TJ (1971) Mechanism of xylem differentiation in Pinus sylvestris L. J Exp Bot 22:67-687

Woźny A, Siwecki R (1991) Ultrastructural studies of oak disease. In: Siwecki R, Liese W (eds) Oak decline in Europe. Instytut Dendrologii PAN, Poznań, pp 315-320

Zimmermann MH (1983) Xylem structure and ascent of sap. Springer, New York

Zobel BJ, Sprague JR (1998) Juvenile wood in forest trees. Springer, New York

Zobel BJ, van Buijtenene JP (1989) Wood variation, its causes and control. Springer, New York 